\title{
Analytical Study of Psychological Capital and Emotional Intelligence as Predictors of Indian Business Students' Performance
}

\author{
D.O.I - 10.51201/12517 \\ https://doi.org/10.51201/12517
}

Dr. Iram Ansari

Assistant Professor, S.B.Patil Institute of Management

Sector 26, NigdiPradhikaran, Pune 411044, Maharashtra, India.

\section{Dr. Aishwarya Gopala krishnan}

Assistant Professor, S. B. Patil Institute of Management

Sector 26, Nigdi Pradhikaran, Pune 411044, Maharashtra, India

Dr. Lakshmi Jasti

Assistant Professor, S.B.Patil Institute of Management

Sector 26, Nigdi Pradhikaran, Pune 411044, Maharashtra, India

\begin{abstract}
In today's fast paced, uncertain, volatile and competitive world, it has become utmost important to find out ways and means to tackle psychological issues and emotional intelligence of individuals. This uncertain and competitive culture not only affects the business world but also affects the performance and life of the students. The present study aims to analyze the impact of Psychological Capital and Emotional Intelligence on the academic performance of the Indian Business graduates. 175 participants responded to a well-structuredquestionnaire. The perception of students was measured using a structured questionnaire. The questions were formulated based on the variables such as emotional intelligence (EI) and psychological capital (Psycap) taking into consideration pervious research. Twenty Four components of Psychological Capital were used (Luthans, Avolio and Avey, 2007) and Fifty components of Emotional Intelligence were used for the study. The performance of students was measured using their SGPA scores. Factor Analysis and Ordinal regression was applied to the collected data. It was found that only a few variables of Psychological capital and Emotional Intelligence affect the
\end{abstract}


performance of Indian Business students. Implications of the findings as well as recommendations for future studies have been discussed.

Keywords: Psychological Capital, Emotional Intelligence, PsyCap, EI.

\section{Introduction:}

The present workplace condition is subjected to a VUCA world i.e. Volatility, uncertainty, complexity and ambiguity. There are a lot of issues which results due to this uncertainty and complexity. To face workplace conditions like these, the Indian Business students need to be fully prepared. Their performance to some extent will reflect their readiness to face situations that will be thrown at them in the future. In order to understand an individual's positive psychological state of development, the psychological capital of the students is measured.Psychological capital is defined as an affirmative condition for individual improvement with the features of self-reliance while dealing with the challenges (self-efficacy), positive expectations for the future success (optimism), being full of determination (hope), and accomplishment in spite of obstacles (resilience). The onset of the $21^{\text {st }}$ century brought in the works of Luthan, (2002) which emphasized that the focus of attention in the field of organizational behavior should center on PositiveOrganizational Behavior (POB), while a lot of study inpsychology and application to human resources, suggests that positive orientation, which could be measured, managed and developed to enhance employees' performance Luthans, Youssef, \&Avolio, 2007). Characteristics such as hope, resilience, confidence and optimism were presented as $\mathrm{POB}$ states, considering that they represent a higher order setting in employees, named as Positive Psychological Capital.This now extensivelyacknowledged construct of Positive PsyCap consists of the positive psychological resources of hope, efficacy, resilience, and optimism (i.e., the "HERO" within) and has been clearly validated to be a higher order core construct (Luthans, Avolio, Avey, \& Norman, 2007) and is positively related to a variety of employee attitudinal, behavioral, and performance outcomes (Avey, Reichard, Luthans, \&Mhatre, 2011; Luthans\& Youssef-Morgan, 2017). Additionally of most relevance to this study, PsyCap has been demonstrated in empirical studies to contribute to desired management education outcomes such as academic performance (Luthans, Luthans, \& Jensen, 2012), student engagement (Luthans, Luthans, \& Palmer, 2016), and student adjustment (HazanLiran\& Miller, 2017). 


\section{Objectives of the study:}

1. To predict the association between psychological capital, emotional intelligence and its effects on Indian Business students' performance.

2. To examine the impact of psychological capital of Business students' performance.

3. To investigate the impact of emotional intelligence of Business students' performance.

\section{Hypotheses of the study:}

H01: There is no association between Psychological Capital and Emotional Intelligence.

H02: Psychological capital does not affect the performance of the business students.

H03: Emotional Intelligence does not affect the performance of the business students.

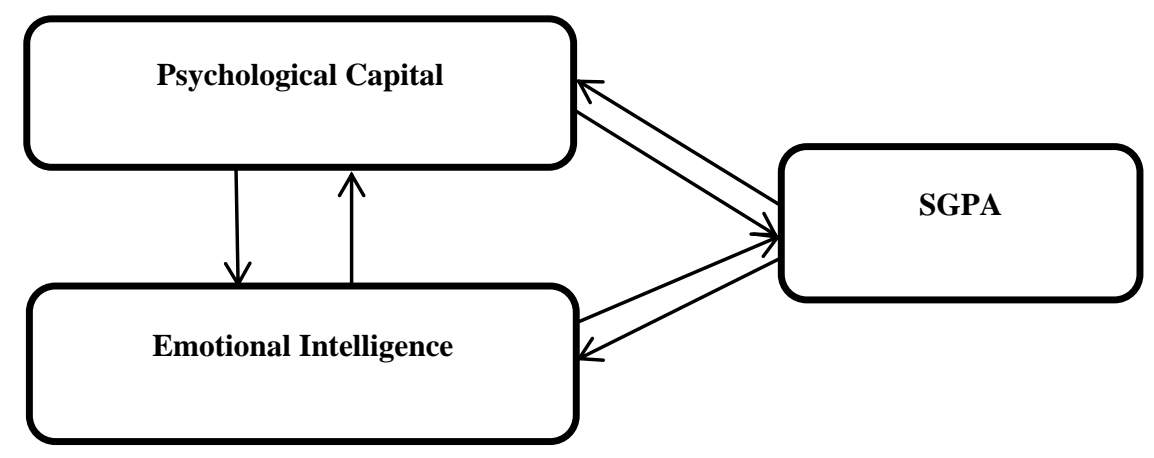

Fig 1. Framework showing the relationship between Psychological capital, Emotional intelligence and SGPA score

\section{Literature Review}

Pradhan.R, Jena., Land, Bhattacharya.,P (2016) researched the relationship between psychological capital (Psycap) and organizational citizenship behavior (OCB) and also studied if the Emotional Intelligenceconstructplays a role in moderating the relationship between Psycap and OCB. The four variables (efficacy, hope, optimism and resiliency) that Psy Cap are unique, measurable, developable, and impactful on performance (Luthans et al., 2004). In the early years businessmen gave utmost importance to the finances, material and other resources but later the role of human resource and its importance was established. And in recent years, businessmen found that the four variables in positive PsyCap are also very important for business and economic growth (Luthans et al., 2004, 2007a; Rego et al., 2012).

It has been observed that there are numerous studies based on analyzing the impact of Psy Cap on adjustment. In 2007, Luthans found that the four variables of Psy Cap either together or separate did create a positive impact on the work performance and job satisfaction of the 
employees. Luthanset.al (2006) investigated and found that there does exist a positive impact on the company's financial performances when the participants' PsyCap was actually enhanced due to training. Luthans et.al (2008) found out that when the employees scored higher in the PsyCap variables of Self efficacy, Hope, optimism and Resilience, it had a positive impact, on performance, satisfaction and commitment of the employees.

A developing number of researchers have investigated the positive effects of PsyCap in the Chinese setting. Wang et al. (2012a,b) indicated that PsyCap helped Chinese medical caretakers and specialists to battle against their work burnout. Cheung et al. (2011) applied PsyCap to research 264 full time Chinese teachers in Mainland China. Results demonstrated that when instructors had high PsyCap, they had higher occupation fulfillment and lower work burnout. What's more, the positive relationship between profound acting and employment fulfillment was additionally strengthened among members with high PsyCap.

Vanno V., Kaemkate W., Wongwanich S.,(2014) tried to find out the relationship between academic performance, perceived group PsyCap, and individual PsyCap of Thai undergraduate students. The results exhibited that academic performance had a positive direct effect on students' PsyCap and positive indirect effect on students' perceived group PsyCap through their own PsyCap. Moreover, students' PsyCap has positive impact on their perception of PsyCap of the group, but there is no reciprocal effect.

Thomas E., and Tankha. G,(2017) in their study, examined the relationship between Big Five Personality traits and PsyCap among final year medical students and secondly, to determine whether Big Five personality traits hold predictive value for PsyCap of final year medical students. Also studies trying to find out the relationship between PsyCap and Creativity of the students (Tsai, Lee, \& Hsu, 2012), coping up mechanism or positive coping up style (Khan, Siraj, \& Li, 2011; Qingquan \& Zongkui, 2009) and physical and psychological well- being (Qingquan \& Zongkui, 2009; Zhong \& Ren, 2009), have been carried out. The major idea was to find out the impact of students' academic performance on their perception of PsyCap, both individually and in groups.

\subsection{Emotional Intelligence:}

Emotional intelligence (EI) can be understood as the ability to perceive, control, and evaluate emotions of self and others. It is the ability of an individual to manage others emotions and have oneself, it has five characteristics self-awareness, managing oneself, motivating oneself, 
Empathy and social skills. It is Daniel Goleman, who introduced the concept of Emotional Intelligence to the wide audience with his work in the form of a book. During his work he found that the qualities which traditionally were associated with leadership such as persistence, intelligence, determination, foresightedness and vision are essential for success remained insufficient. What distinguishes highly effective leaders from others was high degree of emotional intelligence.

Self-Awareness is the ability to understand oneself, know and recognize what you feel and how this affects the behavior and performance. When you are self-aware you tend to realize your potential and limitations. Managing emotions is the ability of a person to keep control on his /her emotions even when he/she is experiencing powerful emotions. This enables the person to avoid hasty decisions in the state of flow of emotions. This enables a person to take responsibility of your own actions. Motivation oneself reflects the ability to move out from any undesired situation and stay focused towards achieving goals. Empathy is the ability of understanding others, the way they feel and understanding their behavior. Self-awareness is the art of understanding your own emotions, it is simple if you are unable to understand your own emotions how you can understand that of others. And social skills are the ability to have a control in relationships and being able to influence others.

Studies have been to find the association of emotional intelligence to various aspects like mental, social and physical health and anxiety and depression. (E. Natalio and F. Pablo, 2014). The result showed EI having high association with anxiety and depression and low association with mental, social and physical health of the university students.C.Stephane and M. Christopherin 2006 tied to find the association of EI and cognitive Intelligence on job performance. The result showed that association between job performance and EI becomes more positive as cognitive intelligence decreases.

L. Paulo, B. Marc, N. John ,(2004) in their study found out that there is positive relationship between ability to manage emotions and quality of social interactions of American college students. Their study also revealed that managing emotions was positively related to quality of interactions with opposite sex people. Libbrecht, N., Lievens, F., Carette, B., \& Côté, S. (2014) in their study tried to find out if EI could predict success of medical students on communication and interpersonal sensitivity, result showed that EI did not predict performance on courses on medical subject domains. 
Boyce, D. A. (2002) in his study found low correlation between emotional intelligence and cognitive ability and no correlation between cognitive ability and academic success existed, but low correlation between emotional intelligence and academic success of Master's level physical therapy students. Since not much of study was conducted to find out the correlation at Management students level were carried out, this study is majorly focused on the same.

\section{Research Methodology:}

Data was collected from 175 Indian Business Studentsof which 84 students were males and 91 students were females. The respondents belonged to first and second year of MBA at college's affiliated to the Savitribai Phule Pune University. Descriptive research design is used and data has been collected through a structured questionnaire designed by focusing on the academic performance of students and statements have been developed related to analyse the impact of psychological capital and emotional intelligence on their academic performance. The responses were collected in a classroom setting. The demographic details such as class, age and gender was obtained from each student who participated in this survey.

24 components of Psychological Capital and 50 components of emotional intelligence were tested. Factor analysis, Correlation and Ordinal Regression was applied to the data collected. The Semester Grade Point Average (SGPA) of the respondents was taken into consideration as a measure of their performance. Factor analysis was applied on the variables to reduce data and variables having an Eigen Value $>1$ was retained. Correlation was applied to the retained variables in order to study the association between Emotional Intelligence and Psychological Capital. Ordinal Linear Regression was also applied to the retained variables in order to test the Goodness of Fit. Out of the Psychological capital parameters, only the Self-Efficacy variables was retained during factor analysis and from the Emotional intelligence parameters, variables related to Self-Awareness and a few variables from managing emotions parameter were retained.

\section{Results and Discussions:}

\subsection{Descriptive statistics:}

The data has been collected through a structured questionnaire. The questionnaire on psychological capital (PsyCap) (i.e. a higher order constellation of positive psychological components that consists of hope, optimism, self-efficacy and resilience), byPCQ-24, Luthans, Avolio, Avey\& Norman, 2007) was used, Likert scale questions ranged from Strongly Agree to Strongly Disagree) and 50 questions on Emotional Intelligence with Likert scale questions 
Out of the Psychological capital parameters, only the Self-Efficacy variables was retained during factor analysis and from the Emotional intelligence parameters, variables related to SelfAwareness and a few variables from managingemotions parameter were retained.

\subsection{Mean, Standard Deviation, Partial Correlation of Psychological Capital and Emotional Intelligence}

\section{Psychological Capital:}

In the PsychologicalCapital component, the highest mean was found for the "I feel confident setting targets/goals in my life" parameter which was 4.50. The second highest mean was found for the, "I feel confident in representing my ideas concerning my life" parameter which was 4.36. Equal weightage of means was found for the "I feel confident analyzing a long-term problem to find a solution concerning my life" and "I feel confident contributing to discussions about strategies on my life" parameters which was 4.26. The lowest mean was found for the "I feel confident contacting people to discuss problems concerning my life" parameter which was 3.80.

\subsection{Emotional Intelligence:}

In the Emotional Intelligence component, the highest mean was found for the parameter "I know when I am happy" whichwas4.78. In the Emotional Intelligence component, the second highest mean was found for the parameter "I know what makes me happy" which was 4.69. In the Emotional Intelligence component, the third highest mean was found for the parameter "Awareness of my own emotions is very important to me at all times" which was 4.65. In the Emotional Intelligence component, the fourth highest mean was found for the parameter "When I am being 'emotional' I am aware of this" which was 4.60. In the Emotional Intelligence component, the fifth highest mean was found for the parameter "I can tell if someone has upset or annoyed me" which was 4.50 .

6.5 Confirmatory Factor Analysis:

Psychological Capital:Table No. 2.KMO Bartlett's Test for Psychological Capital

\begin{tabular}{|c|c|c|}
\hline \multicolumn{2}{|c|}{ KMO and Bartlett's Test } \\
\hline \multicolumn{2}{|c|}{ Kaiser-Meyer-Olkin Measure of Sampling Adequacy. } & 0.893 \\
\hline \multirow{2}{*}{$\begin{array}{c}\text { Bartlett's Test of } \\
\text { Sphericity }\end{array}$} & Approx. Chi-Square & 1748.715 \\
\cline { 2 - 3 } & df & 276 \\
\cline { 2 - 3 } & Sig. & $\mathbf{0 . 0 0 0}$ \\
\hline
\end{tabular}


Source: Primary Data

Bartlett's Test of Sphericity is found to be significant since the p value is $(0.000)$ which is less than 0.05 . Hence, the null hypothesis is rejected.

Table No. 3.Total variance, Percentage and Cumulative percentage variance for Psychological capital

\begin{tabular}{|c|c|c|c|}
\hline \multicolumn{4}{|c|}{ Total Variance Explained } \\
\hline \multirow[b]{2}{*}{ Component } & \multicolumn{3}{|c|}{ Initial Eigenvalues } \\
\hline & Total & $\begin{array}{c}\text { \% of } \\
\text { Variance }\end{array}$ & $\begin{array}{c}\text { Cumulative } \\
\%\end{array}$ \\
\hline $\begin{array}{l}\text { 1.I feel confident analyzing a long-term problem to find a } \\
\text { solution concerning my life }\end{array}$ & 8.312 & 34.634 & 34.63 \\
\hline $\begin{array}{l}2 . \text { I feel confident in representing my ideas concerning } \\
\text { my life }\end{array}$ & 2.142 & 8.927 & 43.56 \\
\hline $\begin{array}{l}3 \text {.I feel confident contributing to discussions about } \\
\text { strategies on my life }\end{array}$ & 1.417 & 5.905 & 49.47 \\
\hline 4.I feel confident setting targets/goals on my life & 1.181 & 4.919 & 54.39 \\
\hline $\begin{array}{l}5 . \text { I feel confident contacting people to discuss problems } \\
\text { concerning my life }\end{array}$ & 1.029 & 4.286 & 58.67 \\
\hline
\end{tabular}

Source: Primary Data

24 components were considered for the study of Psychological Capital; however after Factor analysis only 5 factors could be retained since they had an Eigen value $>1$. Since the rest of the factors were found to be insignificant, they have been discarded. The first component accounts for $34.634 \%$ of the variance, the second accounts to $8.927 \%$, the third component accounts to $5.905 \%$, the fourth component accounts to $4.919 \%$ and the fifth component accounts to $4.286 \%$. 
6.6 Emotional Intelligence: Table No.4. KMO and Bartlett's Test for Emotional Intelligence

\begin{tabular}{|c|c|c|}
\hline \multicolumn{2}{|c|}{ KMO and Bartlett's Test } \\
\hline $\begin{array}{c}\text { Kaiser-Meyer-Olkin Measure of Sampling } \\
\text { Adequacy. }\end{array}$ & 0.825 \\
\hline \multirow{2}{*}{$\begin{array}{c}\text { Bartlett's Test of } \\
\text { Sphericity }\end{array}$} & Approx. Chi-Square & 3334.236 \\
\cline { 2 - 3 } & df & 1225 \\
\cline { 2 - 4 } & Sig. & $\mathbf{0 . 0 0 0}$ \\
\hline
\end{tabular}

Source: Primary Data

Bartlett's Test of Sphericity is found to be significant since the p value is $(0.000)$ which is less than 0.05 . Hence, the null hypothesis is rejected.

Table No.5. Total variance, Percentage and Cumulative percentage variance for Emotional Intelligence

\begin{tabular}{|c|c|c|c|}
\hline \multicolumn{4}{|c|}{ Total Variance Explained } \\
\hline \multirow[b]{2}{*}{ Component } & \multicolumn{3}{|c|}{ Initial Eigenvalues } \\
\hline & Total & $\begin{array}{c}\% \text { of } \\
\text { Variance }\end{array}$ & $\begin{array}{c}\text { Cumulative } \\
\%\end{array}$ \\
\hline 1. I realize immediately when I lose my temper & 11.906 & 23.811 & 23.811 \\
\hline 2. I know when I am happy & 2.363 & 4.726 & 28.538 \\
\hline 3.I usually recognize when I am stressed & 1.932 & 3.864 & 32.402 \\
\hline 4. When I am being 'emotional' I am aware of this & 1.792 & 3.584 & 35.986 \\
\hline $\begin{array}{l}\text { 5.When I feel anxious I usually can account for the } \\
\text { reason(s) }\end{array}$ & 1.596 & 3.191 & 39.178 \\
\hline 6.I always know when I'm being unreasonable & 1.546 & 3.092 & 42.270 \\
\hline $\begin{array}{l}\text { 7.Awareness of my own emotions is very important to } \\
\text { me at all times }\end{array}$ & 1.512 & 3.024 & 45.293 \\
\hline 8.I can tell if someone has upset or annoyed me & 1.452 & 2.905 & 48.198 \\
\hline $\begin{array}{l}\text { 9.I can let anger 'go' quickly so that it no longer affects } \\
\text { me }\end{array}$ & 1.416 & 2.833 & 51.030 \\
\hline
\end{tabular}




\begin{tabular}{|l|l|l|l|} 
10.I know what makes me happy & 1.331 & 2.662 & 53.692 \\
\hline 11.I can 'reframe' bad situations quickly & 1.244 & 2.488 & 56.181 \\
\hline 12.I do not wear my 'heart on my sleeve' & 1.210 & 2.420 & 58.601 \\
\hline 13.Others can rarely tell what kind of mood I am in & 1.150 & 2.299 & 60.900 \\
\hline 14.I rarely 'fly off the handle' at other people & 1.062 & 2.124 & 63.024 \\
\hline 15.Difficult people do not annoy me & 1.032 & 2.064 & 65.089 \\
\hline
\end{tabular}

Source: Primary Data

50 components were used for Emotional Intelligence Capital; however after Factor analysis only 15 factors could be retained since they had an Eigen value $>1$. Since the rest of the factors were found to be insignificant, they have been discarded. The first factor accounts for $23.811 \%$ of the variance, the second accounts to $4.726 \%$, the third accounts to $3.864 \%$, the fourth accounts to 3.584 , the fifth accounts to $3.191 \%$, the sixth accounts to $3.092 \%$, the seventh accounts to $3.024 \%$, the eighth accounts to $2.905 \%$, the ninth accounts to $2.833 \%$, the tenth accounts to $2.662 \%$, the eleventh accounts to $2.488 \%$, the twelfth accounts to $2.420 \%$, the thirteenth accounts to $2.299 \%$, the fourteenth $2.124 \%$ and the fifteenth $2.064 \%$.

Table No.6 Ordinal Regression Model Fitting Information of Psychological capital

\begin{tabular}{|c|c|c|c|c|}
\hline \multicolumn{5}{|c|}{ Model Fitting Information } \\
\hline Model & -2 Log Likelihood & Chi-Square & df & Sig. \\
\hline Intercept Only & 287.357 & & & \\
\hline Final & 261.423 & 25.934 & 14 & 0.026 \\
\hline
\end{tabular}

Source: Primary Data

From the above table it can be seen that the significance value i.e is 0.026 which is $<0.05$. Hence, the null hypothesis is rejected.

Table No.7 Ordinal Regression Goodness- of -fitof Psychological capital

\begin{tabular}{|c|c|c|c|}
\hline \multicolumn{4}{|c|}{ Goodness-of-Fit } \\
\hline & Chi-Square & df & Sig. \\
\hline Pearson & 285.206 & 290 & 0.568 \\
\hline Deviance & 204.411 & 290 & 1 \\
\hline
\end{tabular}

Source: Primary Data

From the above table it is seen that the observed data is having a goodness of fit with the fitted model. The significance value i.e 0.568 is $>0.05$. Thus, the Null Hypothesis is accepted. 
Table No. 8. Ordinal Regression Pseudo R- squareof Psychological capital

\begin{tabular}{|l|r|}
\hline \multicolumn{2}{|c|}{ Pseudo R-Square } \\
\hline Cox and Snell & 0.138 \\
\hline Nagelkerke & 0.152 \\
\hline McFadden & 0.063 \\
\hline
\end{tabular}

Source: Primary Data

The proportion of the variance explained by the Independent variable on the dependent variable is $15.20 \%$.

Table No.9. Ordinal Regression Test of parallel Lines of Psychological capital

\begin{tabular}{|c|c|c|c|c|}
\hline \multicolumn{5}{|c|}{ Test of Parallel Lines } \\
\hline Model & -2 Log Likelihood & Chi-Square & $\mathrm{df}$ & Sig. \\
\hline Null Hypothesis & 261.423 & & & \\
\hline General & $204.814 b$ & $56.609 \mathrm{c}$ & 42 & 0.045 \\
\hline
\end{tabular}

Source: Primary Data

From the above table it can be observed that the significance value i.e 0.045 is $<0.05$. Thus, the null hypothesis is rejected.

Table No.10. Ordinal Regression Model Fitting Information of Emotional Intelligence

\begin{tabular}{|c|c|c|c|c|}
\hline \multicolumn{5}{|c|}{ Model Fitting Information } \\
\hline Model & -2 Log Likelihood & Chi-Square & $\mathrm{df}$ & Sig. \\
\hline Intercept Only & 409.081 & & & \\
\hline Final & 370.726 & 38.355 & 30 & 0.141 \\
\hline
\end{tabular}

Source: Primary Data

From the above table it can be seen that the significance value i.e is 0.141 which is $<0.05$.

Hence, the null hypothesis is rejected.

Table No.11. Ordinal Regression Goodness- of -fitof Emotional Intelligence

\begin{tabular}{|l|r|r|r|r|}
\hline \multicolumn{5}{|c|}{ Goodness-of-Fit } \\
\hline & Chi-Square & df & Sig. \\
\hline Pearson & & 753.31 & 614 & 0 \\
\hline Deviance & 367.614 & 614 & 1 \\
\hline
\end{tabular}

Source: Primary Data

From the above table it is seen that the observed data is having a goodness of fit with the fitted model. The significance value i.e 0 is $>0.05$. Thus, the Null Hypothesis is accepted. 
Table No.12. Ordinal Regression Pseudo R- squareof Emotional Intelligence

\begin{tabular}{|l|r|}
\hline \multicolumn{2}{|c|}{ Pseudo R-Square } \\
\hline Cox and Snell & 0.197 \\
\hline Nagelkerke & 0.217 \\
\hline McFadden & 0.093 \\
\hline
\end{tabular}

Source: Primary Data

The proportion of the variance explained by the Independent variable on the dependent variable is $21.70 \%$.

Table No.13. Ordinal Regression Test of parallel Lines of Emotional Intelligence

\begin{tabular}{|c|c|c|c|c|}
\hline \multicolumn{5}{|c|}{ Test of Parallel Lines } \\
\hline Model & -2 Log Likelihood & Chi-Square & $\mathrm{df}$ & Sig. \\
\hline Null Hypothesis & 370.726 & & & \\
\hline General & $255.221 b$ & $115.506 \mathrm{c}$ & 90 & 0.036 \\
\hline
\end{tabular}

Source: Primary Data

From the above table it can be observed that the significance value i.e 0.045 is $<0.05$. Thus, the null hypothesis is rejected.

\section{Implications of the study:}

The findings of the present study are pertinent to teachers, parents, the education industry, universities and society at large. Management of schools and colleges can arrange training sessions for the Teachers and help them explore work related capabilities, review strategies and receive advice on how to develop their optimism, hope and resilience. Parents will also be able to see the view point of their wards from the emotional intelligence angle through a lot of workshops and discussion sessions organized by the school management which will help them contribute positively towards the emotional well-being of the students. This study shall assist the policy formulators at school, college and University levelto develop and design a curriculum based on emotional intelligence, psychological capital right from the early education. This study should also facilitate Higher Education authorities on how to design and develop processes that would enhance the emotional intelligence and psychological capital of students.Management institutes and Universities may also think of investing on training their faculty and students in order to enhance their EI skills. Once trained well, the Management faculty need to adopt the role of a guardian who can show care and concern for their students, appraise their emotional 
reactions and use emotions to create a very positive environment in the classroom. A greater understanding of the students will facilitate the faculty members a chance to motivate them more to demonstrate inhabitant conduct. Effective curriculum development and classroom management would further help to observe the students' emotional well-being and achieve higher scores in their academics, ultimately enabling them be ready to face the challenges thrown their way in their career and life.Timely understanding of the student's Pyscap and EI levels will also help the faculty in devising ways to motivate them onto the right orientation path since they are future leaders of their organizations and the country.

\section{Conclusions:}

The research findings set out to understand the association between Psychological capital and Emotional intelligence of Indian Business students. The empirical findings of the study show that a partial correlation was observed between the two variables. Also, the ordinal regression between Psychological Capital, Emotional Intelligence and SGPA of the Indian Business students was studied; it was inferred that there is a significant impact of Psychological Capital and Emotional Intelligence on the SGPA of Indian Business Students.

\section{References}

1. "Emotional Intelligence Predicts Academic Performance: A Meta-Analysis," by Carolyn MacCann, PhD, Yixin Jiang, PhD, Luke Brown, MSc, and MicaelaBucich, BPsych, The University of Sydney; Kit Double, PhD, Oxford University, and AmiraliMinbashian, PhD, University of New South Wales Sydney. Psychological Bulletin, published online Dec. 12, 2019

2. Avey, James B.; Luthans, Fred; Smith, Ronda M.; and Palmer, Noel F., "Impact of Positive Psychological Capital on Employee Well-Being Over Time" (2010).Management Department Faculty Publications. 55. https://digitalcommons.unl.edu/managementfacpub/55

3. Bergheim, K., Nielsen M.B., Mearns, K, Eid, J (2015) The relationship between psychological capital, job satisfactionand safety perceptions in the maritime industry, Safety Science 74 (2015) 27-36

4. Bradshaw, F. B. (2008). Exploring the relationship between emotional intelligence and academic achievement in African American female college students (Unpublished doctoral dissertation). College of Notre Dame of Maryland, Baltimore, MD. 
5. Castro-Johnson, M., \& Wang, A. Y. (2003).Emotional intelligence and academic performance of college honors and non-honors freshmen. Journal of the National Collegiate Honors Council, 4, 105-115. Retrieved fromhttp://digitalcommons.unl.edu/nchcjournal/

6. Collins, S. B. (2012). The emotional intelligence profiles and cognitive measures of nurse anaesthesia students in the South-Eastern United States (Unpublished doctoral dissertation).Andrews University, Berrien Springs, MI.

7. Colston, $R$. (2008). The relationship between emotional intelligence and academic achievement: Implications of birth order based on social rank for nontraditional adult learners (Unpublished doctoral dissertation). Capella University, Minneapolis, MN.

8. Fallahzadeh $H$ (2011) The Relationship between Emotional Intelligence and Academic Achievement in medical science students in Iran. Procedia - Social and Behavioral Sciences, Vol 30, $1461-1466$

9. Fayombo, G. A. (2012). Relating Emotional Intelligence to Academic Achievement among University students in Barbados. The International Journal of Emotional Education, 4, 43-54.

10. Hodzic, S., Scharfen, J., Ripoll, P., Holling, H., \&Zenasni, F. (2018). How efficient are emotional intelligence trainings: A meta-analysis. Emotion Review, 10, 138 -148. http://dx.doi.org/10.1177/1754073917708613

11. Hogan, M. J. (2003). Prediction of grade point average and retention in first-year students by social and emotional competencies (Unpublished)

12. Johnson, G. D. K. (2008). Learning styles and emotional intelligence of the adult learner (Unpublished doctoral dissertation).Auburn University, Auburn, AL.

13. Mellao, N., Monico L.D.S.M (2013) The Relation Between Emotional Intelligence And Psychological Capital Of Employees, International Journal of Developmental and Educational Psychology, INFAD Revista de Psicología, Nºl-Vol.2. ISSN: 0214-9877. pp:545-550

14. Miulescu, T., Chraif, M. Aniţei,M, Iliescu, A. Bârcă, A. (2012).The influence of faculty specialization on deductive reasoning in young Romanian students, Procedia - Social and Behavioral Sciences, Elsevier, Volume 33, 2012, Pages 1063-1066 
15. Mónico, L., Mellão, N., Nobre-Lima, L.,Parreira, P., Carvalho, C. (2016) Emotional Intelligence And Psychological Capital: What Is The Role Of Workplace Spirituality?Revista Portuguesa de Enfermagem de Saúde Mental, ESPECIAL 3 (ABR.,2016), 45-50

16. Pradhan et al., (2016), Impact of psychological capital on organizational citizenship behavior: Moderating role of emotional intelligence. Cogent Business \&Management,3: 1194174

17. Saeed, I., Khan, S.,Qadir, G., (2017),Effect of Psychological Capital and Emotional Intelligence on Employee's Job Performance,Journal of Business and Tourism,Volume 03 Number 02, ISSN: 2520-0739, 121-138.

18. Saithong-in, Supapan and PhaprukbarameeUssahawanitchakit. 2016. Psychological Capital and Job Performance: an Empirical Research of Certified Public Accountants (CPAs) in Thailand. The Business and Management Review. Vol. 7. pp. 499-506.

19. Simons,J. Buitendach, H. (2013) , Psychological capital, work engagement and organisational commitment amongst call centre employees in South Africa, S.A journal of Industrial Psychology, Volume.39 N-2 ISSN 0258-5200

20. Tankha, G., Thomas E.R. () Big Five Personality And Psychological Capital Among Final Year Medical Students, International Journal of Advanced Research. 5(1), 1121 1126. http://dx.doi.org/10.21474/IJAR01/2861

21. Ugwuanyi, C., Okeke, C., \&Asomugha, C. (2020),.Prediction of learners' mathematics performance by their emotional intelligence, self-esteem and self-efficacy, Cypriot Journal of Educational Sciences, 15(3), 492-501. 